\title{
A Case for Systematic and Methodical Design Engineering
}

\author{
W. Ernst Eder \\ Royal Military College of Canada (retired) \\ eder-e@kos.net
}

\begin{abstract}
Engineering aims to provide technical processes (TP) and technical systems (TS) to solve a specific task. The human aspects of designing to establish these TP and TS include action modes, expertise, and competencies. These lead to a conclusion that systematic and methodical design engineering is essential.
\end{abstract}

\section{Introduction}

Engineering in general has aims that are different to science, the name alone indicates a part of that difference - 'engineering' implies a verb, an activity to produce something useful, 'science' implies a noun, a body of codified knowledge.

Engineering aims to provide processes and technical systems to solve a specific task, to help in performing a desired transformation process, independent of the degree to which the applied phenomena are understood, especially in their interactions. The main regions of activity for engineering are designing, manufacturing/implementing, operating, procuring and supervising. Among these, design engineering as an activity is probably least understood, its investigation only reaches back about 70 years [1,2]. Previous papers have highlighted some aspects $[3,4,5,6,7,8]$ Various aspects need to be explored in order to justify the need for students to learn systematic and methodical design procedures during their education.

\section{Human Aspects Of Design}

Designing in engineering has technical, economic, human, sociological and psychological dimensions, see figure 1 , which needs aspects, context and consequences of psychology.

Even the human dimension has several aspects which together characterize the processes and activities of design engineering. These should be understood as near-orthogonal scales which combine to provide this characterization.

\subsection{Action Modes}

According to Müller [9], human designers exhibit three kinds of action modes in design engineering:

(a) Normal operation (intuitive, second nature procedure, routine) runs activities from the subconscious in a learned and experienced way, at low mental energy, giving an impression of competence $[11,12,13]$. If difficulties arise, the action departs from the normal, and higher mental energy is needed.

(b) Risk operation uses the available experiences (and methods) together with partially conscious rational and more formalized methods, in an unplanned 'trial and error' behavior (but see comments in section 2.2 , which can occasionally be very effective.

(c) Safety or rational operation needs conscious planning for systematic and methodical work, with conscious processing of a plan, because competence is in question, but this mode must be learned before attempting to use it.

Forms (a) and (b) are obviously also available to industrial designers and practitioners of integrated product development.

Normal, routine, operation is mainly preferred and carried out by an individual. Risk operation tends to demand team activity, the task becomes non-routine, consultations can and should take place - 'bouncing ideas off one another', obtaining information and advice from experts, reaching a consensus on possibilities and preferred actions, etc. Consultations are best if the participants are of approximately equal experience or status, or if there is a large gap in experience from questioner to consultant. Personal contact tends to be quicker at lower mental energy than obtaining information from (written) records $[14,15]$.

Non-routine situations often produce critical situations in a design process $[16,17,18,19]$, e.g. during: (a) defining the task, analysis and decisions about goals; (b) searching for and collecting information, recorded 


\section{Figure 1 Role of Design Engineering in Context of Technology and Society [2]}

or remembered, (c) searching for solutions; (d) analyzing proposed solutions; (e) deciding about solutions; (f) managing disturbances and conflicts, individual or team.

As a problem of design engineering appears less routine, for risk and safety operation, designers need advice how they can proceed to overcome the barriers. Design engineering, especially with the help of Engineering Design Science [1,2,20], offers several theories, models of transformation processes and technical systems, methods derived from these theories, and other pragmatically developed methods, that are generally not available to artistic design disciplines. But these models and methods must have been learned, and be sufficiently familiar to the designer before he/she attempts to use them on a serious problem - a problem for education.

It is only in safety/rational operation using a theorybased systematic and methodical approach $[1,2]$ that a full record of all transactions and decisions can be generated and recorded. Normal and risk operation requires a post-hoc recovery of this information to generate a reasonably full record. Systematic design engineering is the heuristic-strategic use of a theory to guide the design process. Methodical design engineering is the heuristic use of newly developed and established methods in engineering design, including theory-based and 'industry best practice', strategic and tactical, formalized and intuitive methods.

The proportion of systematic, methodical work should ideally be increased, especially for team consultations. This methods-conscious mode of working, and appropriately documented results, should be demanded by higher management.

\subsection{Expertise}

As adapted from Dorst [21], Hubert Dreyfus [22,23] distinguishes seven levels of expertise, corresponding with seven ways of perceiving, interpreting, structuring and solving problems within an amalgam of three worlds - a theory world, a subjective internal world, and an objective external world:

1. Novice: A novice will consider the objective features of a situation, as they are given by the experts, and will follow strict rules to deal with the problem.

2. Advanced Beginner: For an advanced beginner the situational aspects are important, there is a sensitivity to exceptions to the 'hard' rules of the novice. Maxims and heuristics [24] are used for guidance through the problem situation.

3. Competent: A competent problem solver selects the elements in a situation that are relevant, and chooses a plan to achieve the goals. This selection and choice can only be made on the basis of a much higher involvement in the design situation than displayed by a novice or an advanced beginner. Problem solving at this level involves activities of seeking of opportunities, and building up expectations. At this level of involvement the problem solving process takes on a 'trial and error' character (but see below), and there is a clear need for learning 
and reflection that was absent in the novice and the beginner .

4. Proficient: A proficient problem solver immediately sees the most important issues and appropriate plan, and then reasons out what to do.

5. Expert: The real expert responds to a situation intuitively, i.e. in 'normal operation' [14]; and performs the appropriate action straight away. There is no obvious (externally observable) problem solving and reasoning that can be distinguished at this level of working. This is actually a very comfortable level at which to function, and many professionals do not progress beyond this point.

6. Master: With the next level, the master, a new uneasiness creeps in. The master sees the standard ways of working that experienced professionals use not as natural but as contingent. A master displays a deeper involvement into the professional field as a whole, dwelling on success and failure. This attitude requires an acute sense of context, and openness to subtle cues. In his/her own work the master will perform more nuanced appropriate actions than the expert.

7. Visionary: The world discloser or 'visionary' consciously strives to extend the domain in which he/she works. The world discloser develops new ways things could be, defines the issues, opens new worlds and creates new domains. To do this a world discloser operates more on the margins of a domain, paying attention to other domains as well, and to anomalies and marginal practices that hold promises for a new vision of the domain.

Vladimir Hubka was obviously a visionary in this sense with respect to design engineering, its products and its processes $[1,2,20]$.

The last sentence of item ' 3 . Competent' needs further clarification. Progress from one level to a next higher level requires some added learning and reflection - formal or informal learning by experience, obtaining relevant information from other people or publications, etc. This learning must of necessity include both object information about the product being designed, and design processes information, preferably in a non-threatening (educational) environment, i.e. to achieve an improvement of the mind-internalized theory. The 'trial and error character' is only an apparent phenomenon, it reflects a normal/routine level of operation [15] where the applied theories, steps and methods are no longer conscious and externally recognizable. For this reason it becomes difficult (e.g. in an educational situation) to perform an examination of the existing internalized design process knowing of a designer.

An 'intuitive' response, as claimed for the ' 5 . Expert', is also more or less to be expected at all levels of expertise, as the relevant theory and method becomes well enough internalized to run routinely, and examination becomes more difficult.

Only a few engineering designers need to reach the highest levels - but all engineering graduates should be exposed to this discipline of Engineering Design Science [1,2,20]. Especially for design engineering, the theories, models and methods of Engineering Design Science offer a basis for organizing, acquiring and understanding this knowledge in context.

Any one designer necessarily shows different levels of expertise for different types of problem, and progression through these levels is not uniform. Especially in critical situations, and situations where risk or safety operation becomes necessary, the local level of expertise is low. For the novice, almost all problems appear as requiring risk or safety operation.

\subsection{Competencies}

Engineering education, and continuing learning during practice (see also [25]) should aim to achieve several competencies of engineers, technologists, technicians, etc., in analyzing and (more importantly) in synthesizing (designing) technical systems. This requires knowing, internalized information of objects and design processes, and awareness of where to find recorded and experiential available information. Competencies includes [11,12,13]:

- heuristic and practice related competency ability to use experience and precedents [26], design principles [2,27], heuristics [24], information and values (e.g. of technical data) as initial assumptions and guidelines, etc.;

- branch and subject related competency knowledge of a TS-'sort' within which designing is expected (completed during employment); typical examples of TS-'sorts' should be included in education (i.e. in addition to conventional and newer machine elements, e.g. electronic), and should also show the engineering sciences, pragmatic information, knowledge and data [28,29], and examples of realized systems;

- methods related competency - knowledge of and ability to use methods, following the methodical instructions under controlled conditions, and eventually learning them well enough to use them intuitively - for diagnostics, analysis, experimentation, information sear- 
ching, representing (in sketches and computer models), creativity [9], innovative thinking, and systematic synthesizing [30,31,32];

- systems related competency - ability to see beyond the immediate task, analytically / reductionistically and synthetically / holistically, to take account of the complex situation and its implications, e.g. life-cycle engineering [33,34,35,36,37,38], or economics;

\& personal and social competency - including team work, people skills, trans-disciplinary cooperation, obtaining and using advice, managing subordinates, micro- and macroeconomics, social and environmental awareness, and cultural aspects, etc. [39]; and the associated leadership and management skills; and

- socio-economic competency - including awareness of costs, prices, returns on investment, micro- and macro-economics, politics, entrepreneurial and business skills, etc.

These competencies are related to creativity. Methods-related competency is probably the least emphasized among the skills and abilities acquired during the usual educational curricula in engineeriug, followed closely by personal/social and socioeconomic competencies. Even the heuristic and branch-related competencies are swamped by the emphasis on analytical mathematical tools.

When a method is well known to the designer, it can at best be run from the sub-conscious, and the users can then even deny that they are using the method - a 'routine' action mode. For the other action modes, it is necessary for engineering designers to learn methodology during their engineering education. Then the methods are familiar enough to apply, even if there is resistance from a supervisor. Learning 'on the job' is difficult, unless it is supported by management. The beneficial results of teaching design methodology have been demonstrated [40,41 $42,43]$, after 25 years of teaching, and after some graduates entered industry as engineering designers. A good understanding of the method and its underlying theory is important for theory_based methods $[1,2,20,27]$. Then the procedure that is prescribed or recommended for the method makes more sense, therefore producing less stress, and a better direction towards the goals.

\section{Closure}

Design engineering is such an important element of human activity, that it should feature in all years of study in engineering education. Systematic and methodical working to enable creativity should be learned in a relatively 'safe' environment, before any situations of risk or rational operation arise. This then supports life-long learning to allow a practitioner to move higher in the scale of expertise and competencies. The understanding delivered by EDS as basis should also help to coordinate the subjects in a curriculum.

\section{References}

[1] Hubka, V., \& Eder, W.E. (1996) Design Science: Introduction to the Needs, Scope and Organization of Engineering Design Knowledge, London: Springer-Verlag, http://deseng.ryerson.ca/DesignScien ce/, completely revised edition of Hubka, V. and Eder, W.E. (1992) Einführung in die Konstruktionswissenschaft (Introduction to Design Science), Berlin, Springer-Verlag

[2] Eder, W.E. \& Hosnedl, S. (2008) Design Engineering: A Manual for Enhanced Creativity, Boca Raton: CRC Press

[3] Eder, W.E., Hubka, V. and Benabdallah, H. (2004) 'Educating for Engineering Design using Design Science', in Proc. Inaugural CDEN Design Conference, McGill University, Montreal, July 29 - 30, 2004, on CD-ROM

[4] Eder, W.E. (2005) 'Machine Elements Revision and Outlook for Design Education', in Proc. Second CDEN International Conference, University of Calgary, Alberta, 18-19 July 2005 at Kananaskis Resort, paper 10006 on CDROM

[5] Eder, W.E. (2005) 'Application of Design Methodology for Education', in Proc. Second CDEN International Conference, University of Calgary, Alberta, 18-19 July 2005 at Kananaskis Resort, paper 10007 on CD-ROM

[6] Eder, W.E. (2006) 'Properties of Technical Systems - Key to Crossing Design Boundaries', in Proc. CDEN Conference 2006 Toronto, 24-26 July 2006, on CDROM

[7] Eder, W.E. (2006) 'Case Study in Design Engineering', in Proc. CDEN Conference 2006 Toronto, paper 28, on CD-ROM

[8] Eder, W.E. (2007) 'Design Engineering Not Just Applied Science', in Proc. CDEN/CCEE - Canadian Design Engineering Network and Canadian Conference on Engineering Education, 
22-24 July 2007, U. of Manitoba, Winnipeg, Manitoba, on CD-ROM

[9] Eder, W.E. (ed) (1996) WDK 24 - EDC Engineering Design and Creativity Proc. of the Workshop EDC, Pilsen, Czech Republic, November 1995 Zürich: Heurista

[10] Müller, J. (1991) 'Akzeptanzbarrieren als berechtigte und ernst zu nehmende Notwehr kreativer Konstrukteure - nicht immer nur böser Wille, Denkträgheit oder alter Zopf' (Acceptance Barriers as Justified and Serious Defence Reaction of Creative Designers - not always Ill Will, Thinking Inertia or Old Hat), in Hubka, V. (ed.) (1991) WDK 20: Proc. of ICED 91 Zürich, Zürich: Heurista, p. 769-776; and 'Acceptance Barriers as Justified and Serious Defence Reaction of Creative Designers - not always only Ill Will, Thinking Inertia or Old Hat,' in [9], 1996, p. 79-84

[11] Eder, W.E. and Hubka, V. (2001) 'Curriculum, Pedagogics, and Didactics for Design Education', in (2001) WDK 28:

Proc. International Conference on Engineering Design, ICED01 Glasgow, 2123 August 2001, London: IMechE., Vol 4, p. 285-292

[12] Pahl, G. (scientific director), 'Ergebnisse der Diskussion' (Results of the Discussions), in G. Pahl (ed.) (1994) Psychologische und Pädagogische Fragen beim methodischen Konstruieren: Ergebnisse des Ladenburger Diskurses vom Mai 1992 bis Oktober 1993 (Psychological and Pedagogic Questions in Systematic Designing: Results of a Discourse at Ladenburger from May 1992 to October 1993), Köln: Verlag TÜV, p. 1-37

[13] Pahl, G., 'Transfer Ability as Educational Goal - Results of a Discourse at Ladenburg', in [9], p. 133-138; and Hubka, V. (ed.) (1995) WDK 23 - Proc. International Conference on Engineering Design - ICED 95 Praha, Zürich, Heurista, p. 247-252

[14] Ahmed, S. and Wallace, K. (2004) 'Identifying and Supporting the Knowledge Needs of Novice Designers within the Aerospace Industry', Jnl. Eng. Design, Vol. 15 No. 5, p. 475-492

[15] Müller, J. (1990) Arbeitsmethoden der Technikwissenschaften - Systematik, Heuristik, Kreativität (Working Methods of Engineering Sciences, systematics, heuristics, creativity), Berlin: SpringerVerlag

[16] Frankenberger, E., Badke_Schaub, P. and Birkhofer, H. (1997) 'Factors Influencing Design Work: Empirical Investigations of Teamwork in Engineering Design Practice', in Riitahuhta, A. (ed.) (1997) WDK 25 Proc. ICED 97 Tampere, Tampere University, p. 2/387-392

[17] Frankenberger, E. and Badke_Schaub, P. (1997) 'Integration of Group, Individual and External Influences in the Design Process', in Frankenberger, E., Badke-Schaub, P. and Birkhofer, H. (eds.), Designers: The Key to Successful Product Development, Berlin/Heidelberg: Springer-Verlag, 1997

[18] Frankenberger, E. (1997) Arbeitsteilige Produktentwicklung (Product Development with Task Distribution), Fortschrittsberichte VDI Reihe 1, Nr. 291, Düsseldorf: VDI

[19] Frankenberger, E. and Badke-Schaub, P. (1998) 'Role of Critical Situations in Design Processes and Education', in Proc. WDK International Workshop PDE Pedagogics in Design Education, Pilsen: West Bohemia University, 1998

[20] Hubka, V., \& Eder, W.E. (1988) Theory of Technical Systems, New York: Springer_Verlag, completely revised translation of Hubka, V. (1984) Theorie Technischer Systeme (2 ed, revised from Theorie der Maschinensysteme 1974), Berlin: Springer-Verlag

[21] Dorst, K. and Reymen, I. (2004) 'Levels of expertise in design education', in Proc. International Engineering and Product Design Education Conference, 2-3 September 2004, Delft, The Netherlands

[22] Dreyfus H.L. (2003) 'From Socrates to Artificial Intelligence: The Limits of RuleBased Rationality', unpublished lecture notes of the first 2003 Spinoza Lecture at the University of Amsterdam

[23] Dreyfus H.L. (2003) 'Can there be a better source of meaning than everyday practices?', unpublished lecture notes of the second 2003 Spinoza Lecture at the University of Amsterdam

[24] Koen, B.V. (2003) Discussion of The Method: Conducting the Engineer's Approach to Problem Solving, New York: Oxford Univ. Press

[25] Eder, W.E. (2002) 'Education for Engineering and Designing', in Proc. 
International Design Conference - Design 2002, Dubrovnik, May 14 - 17, 2002, on CD-ROM

[26] Booker, P.J. (1962) 'Principles and Precedents in Engineering Design', London: Inst. of Engineering Designers

[27] Hubka, V. and W.E. Eder (1992) Engineering Design, Zürich: Heurista $\left(2^{\text {nd }}\right.$ edition of Hubka, V., Principles of Engineering Design, London: Butterworth Scientific, 1982, translated and edited by W.E. Eder from Hubka, V., WDK 1 Allgemeines Vorgehensmodell des Konstruierens (General Procedural Model of Designing), Zürich, Heurista, 1980)

[28] Constant, E.W., II (1980) The Origins of the Turbojet Revolution, Johns Hopkins Studies in the History of Technology, Baltimore: Johns Hopkins U.P.

[29] Vincenti, W.G. (1990) What Engineers Know and How They Know It Analytical Studies from Aeronautical History, Baltimore: Johns Hopkins Univ. Press

[30] Hubka, V. and Schregenberger, J.W. (1988) 'Eine neue Systematik konstruktionswissenschaftlicher Aussagen Ihre Struktur und Funktion' (A New Systematic Order for Design-Scientific Statements - its Structure and Function), in Hubka, V., Baratossy, J. and Pighini, U. (eds.), WDK 16: Proceedings of ICED 88, Budapest: GTE and Zürich: Heurista, Vol. 1, p. 103-117

[31] Hubka, V. (1988) 'A Curriculum Model Applying the Theory of Technical Systems', in W.E. Eder and G. Kardos (guest eds.), Special Issue on Education for Engineering Design, Int.J.Appl.Engng.Ed. Vol. 4 No. 3, p. $185-192$

[32] Hubka, V. and Eder, W.E. (2001) 'Theory of technical systems and engineering design synthesis', in Amaresh Chkrabarti (ed.), Engineering Design Synthesis, London: Springer-Verlag, p. 49-66

[33] Berendt, S., Jasch, Chr., Peneda, M.C. and Weenen, H.van, Life Cycle Design, A Manual for Small and Medium-Sized Enterprises, Berlin: Springer-Verlag, 1997

[34] Eder, W.E., 'Designing and Life Cycle Engineering - A Systematic Approach to Designing', Proc. Inst. Mech. Eng. (UK), Part B, Jnl. of Eng. Manufacture, Vol. 215, No. B5, 2001, p. 657-672
[35] Ernzer, M. and Birkhofer, H., 'Life Cycle Design for Companies - Scaling Life Cycle Design Methods to the Individual Needs of a Company', in Folkeson, A., Gralén, K., Norell, M. and Seligren, U. (eds.), DS 31 Proc. ICED 2003 Stockholm, Glasgow: The Design Society, 2003, p. 393-394

[36] Graedel, T.E., Streamlined Life Cycle Assessment, Upper Saddle River, NJ: Prentice-Hall, 1998

[37] Guine, J.G. (ed.), Handbook on Life Cycle Assessment, Dordrecht: Kluwer Academic, 2002

[38] Wimmer, W. and Züst, R., Ecodesign Pilot, Dordrecht: Kluwer, 2003

[39] Eder, W.E., 'Social, Cultural and Economic Awareness for Engineers', in CSME Forum 2002, Queen's University, Kingston, ON, abstract p. 130, on CD-ROM, 2002

[40] Dörner, D., Ehrlenspiel, K., Eisentraut, R. and Günther, J.(1995) 'Empirical Investigation of Representations in Conceptual and Embodiment Design,' in Hubka, V. (ed.) WDK 23 - Proc. International Conference on Engineering Design - ICED 95 Praha, Zürich, Heurista, p. 631-637

[41] Fricke, G. and Pahl, G. (1991) 'Zusammenhang zwischen Personenbedingtem Vorgehen und Lösungsgüte' (Relationship between Personally Conditioned Procedure and Quality of Solution), in Hubka, V. (ed.) WDK 20: Proc. of ICED 91 Zürich, Zürich: Heurista, p. 331-341

[42] Günther, J. and Ehrlenspiel, K. (1997) 'How Do Designers from Practice Design?' in Frankenberger, E., Badke-Schaub, P. and Birkhofer, H. (eds.), Designers: The Key to Successful Product Development, Berlin/Heidelberg: Springer-Verlag, p. 8597

[43] Pahl, G., Beitz, W., Feldhusen, J. and Grote, H-K., Engineering Design (3 ed.), London: Springer-Verlag, 2007 (1 ed. 1984) (Edited and translated by $\mathrm{K}$. Wallace and L. Blessing), translated from 2003-5th ed. of Pahl, G. and Beitz, W., Feldhusen, J. and Grote, H-K. Konstruktionslehre, Methoden und Anwendungen, (7 ed.) Berlin/Heidelberg: Springer-Verlag, 2007 (1 ed. 1977) 